\title{
Pemanfaatan Informasi Tentang Balita Usia 12-59 Bulan pada Buku KIA dengan Kelengkapan Pencatatan Status Gizi di Buku KIA
}

\author{
Dzul Istiqomah Hasyim ${ }^{1}$, Apri Sulistianingsih ${ }^{2}$ \\ ${ }^{1,2}$ Dosen STIKes Muhammadiyah Pringsewu \\ Jl. Makam KH Ghalib, No. 112,, Pringsewu Utara, Kecamatan Pringsewu, Pringsewu Utara, Kec. Pringsewu, \\ Kabupaten Pringsewu, Lampung 35373 \\ dzulistiqomah6@gmail.com, sulistianingsih.apri@gmail.com
}

\begin{abstract}
ABSTRAK
Pemanfaatan buku Kesehatan Ibu dan Anak (KIA) yang dilakukan dengan baik dapat meningkatkan kesehatan bagi ibu dan anak. Salah satu fungsi buku KIA adalah mencatatan status gizi balita. Hal ini menjadi penting sebagai upaya deteksi dini gangguan gizi pada balita. Fungsi buku KIA adalah sarana pencatatan ibu dan anak, alat komunikasi dan edukasi untuk kesehatan balita dan ibu. Penelitian ini bertujuan untuk mengetahui pemanfaatan informasi tentang balita usia 12-59 bulan pada buku kia dengan kelengkapan pencatatan status gizi di buku KIA di Desa Margakaya Pringsewu Lampung. Penelitian ini merupakan penelitian observasional analitik dengan pendekatan cross sectional. Kelompok sasaran populasi adalah seluruh ibu yang memiliki balita usia 12-59 bulan di Desa Margakaya berjumlah 240 orang. Besar sampel dihitung menggunakan total sampling yang didapatkan sebanyak 226 orang jumlah sampel yang memenuhi kriteria. Hasil uji statistik diperoleh nilai pvalue $\leq 0,001$. Hal ini berarti dari hasil penelitian menunjukan adanya hubungan pemanfaatan informasi tentang balita usia 12-59 bulan pada buku KIA dengan kelengkapan pencatatan tumbuh kembang di buku KIA di Desa Margakaya Pringsewu Lampung. Secara statistik diperoleh nilai OR=16.466 (5.540 - 38.941), yang berarti ibu yang tidak memanfaatkan informasi pada buku KIA memiliki risiko 16 kali catatan gizi balita tidak lengkap dibandingkan ibu yang memanfaatkan informasi tentang balita 12-59 bulan di buku KIA.
\end{abstract}

Kata kunci: Balita, Buku KIA, Status gizi

\section{ABSTRACT}

Utilization of Maternal and Child Health Book $(\mathrm{MCH})$ can improve the health of mothers and children. One of the functions of KIA book is to record the nutritional status of children. This becomes important as an early detection of nutritional disorders in infants. The functions of MCH books are: maternal and child recording facilities, communication and education tools for worker and maternal health. This study aims to determine the Relationship Use of Information About Toddlers Age 12-59 Months On MCH Books With Completed Listing of Nutrition Status In MCH Book In Margakaya Pringsewu Village Lampung. This research is an observational analytic research with crossectional approach. The target population group is all couples of mothers who have children under 12-59 months in Margakaya Village amounted to 240 people. The sample size was calculated using the total sampling obtained as many as 226 people the number of samples meeting the criteria. Statistical test results obtained $p$-value $=<0.001$ so $\mathrm{p}<\alpha=0.05$, then HA received and H0 rejected. This means that the results of research shows the relationship of information utilization of children aged 12-59 months in KIA book with completeness of recording of growth in the book KIA in Margakaya Pringsewu Lampung Village. Statistically obtained value of OR $=16.466$ (5.540 - 38.941), which means that mothers who do not take advantage of information on the $\mathrm{MCH}$ handbook have a risk 16 times the nutritional record of children under five is incomplete compared to mothers who use information about children under five 12-59 months in the KIA book. 


\section{Pendahuluan}

Soetjiningsih (2015) menyatakan bahwa usia balita merupakan periode penting untuk menentukan kualitas masa depan anak karena tumbuh kembang fisik, kognitif, keterampilan sosial, emosi termasuk perkembangan kepribadiannya berlangsung dengan pesat. Perkembangan normal pada anak perlu dipantau secara rutin karena dapat dijadikan dasar untuk mengetahui gangguan tumbuh kembang $^{(1)}$.

Berdasarkan data Survei Demografi Kesehatan Indonesia (SDKI) Angka Kematian Bayi (AKB) di Indonesia masih tinggi yaitu 32 per 1000 kelahiran hidup ${ }^{(2)}$. Kebijakan dan berbagai upaya pemerintah untuk menurunkan angka kematian bayi dengan Gerakan Sayang Ibu (GSI), Making pregnancy Safer dan pengadaan buku KIA. Informasi yang terdapat dalam buku KIA diharapkan dapat meningkatkan pengetahuan ibu terkait dengan kesehatan ibu dan anak. Buku KIA selain sebagai alat untuk pencatatan juga digunakan sebagai alat untuk memonitor kesehatan anak dalam pertumbuhan dan perkembangan ${ }^{(3)}$.

Berdasarkan data dari laporan Dinas Kesehatan Provinsi Lampung didapatkan jumlah kasus gizi buruk di Provinsi Lampung pada Tahun 2013- 2014 menurun dimana jumlah kasus gizi buruk pada tahun 2014 sebanyak $10.3 \%$ pada gizi buruk. Pada tahun 2013, berdasarkan berat badan menurut umur didapatkan kasus gizi buruk di Kabupaten Pringsewu sebanyak 11.9\%, dan $6.8 \%$ gizi kurang. Selain itu kasus gangguan gizi lainnya adalah balita pendek.
Di Kabupaten Pringsewu ditemukan sebanyak $24.4 \%$ kasus balita pendek, dan $12.6 \%$ balita sangat pendek. Gangguan gizi ini dapat diatasi salah satunya dengan upaya pemantauan status gizi balita.

Kajian di Jepang menjelaskan, penggunaan buku pencatatan kesehatan ibu dan anak dapat memberikan garansi asuhan berkelanjutan pada ibu dan anak. Salah satu program yang digunakan pada anak pemberikan edukasi nutrisi. Banyak negara telah menjalankan program serupa untuk meningkatkan kesehatan ibu dan anak ${ }^{(4)}$. Hal yang sama dilakukan di Kenya yang mengembangkan buku kesehatan ibu dan anak sebagai sarana dalam informasi, pencatatan dan edukasi untuk menurunkan kematian ibu dan anak. ${ }^{(5)}$

Di Indonesia, Departemen Kesehatan bekerja sama dengan Japan International Cooperation Agency (JICA) melalui proyek KB/KIA pada tahun 1989-1994 di Jawa Tengah dalam mengembangkan Buku Kesehatan Ibu dan Anak (KIA) sebagai salah satu media yang dapat digunakan untuk memantau status gizi balita ${ }^{(6,7)}$, Sehingga penyimpangan pertumbuhan dan perkembangan dapat terdeteksi dini (Depkes, 2015). Hal tersebut sesuai dengan fungsi buku KIA, salah satunya yaitu Fungsi buku KIA sebagai sarana pencatatan status kesehatan ibu dan anak, sarana edukasi dan sarana informasi ${ }^{(8)}$. 
Dzul Istiqomah Hasyim, Apri Sulistianingsih. Pemanfaatan Informasi Tentang Balita Usia 12-59 Bulan Pada Buku KIA Dengan Kelengkapan Pencatatan Status Gizi Di Buku KIA Doi :

Penggunaan Buku KIA merupakan salah satu strategi pemberdayaan masyarakat terutama keluarga dalam memelihara kesehatan dan mendapatkan pelayanan kesehatan ibu dan anak yang berkualitas. Buku KIA berisi informasi dan materi penyuluhan tentang gizi dan kesehatan ibu dan anak, kartu ibu hamil, KMS balita serta catatan pelayanan kesehatan ibu dan anak. Buku KIA dibawa setiap kali ibu atau anak datang ke tempat-tempat pelayanan kesehatan di mana saja untuk mendapatkan pelayanan $\mathrm{KIA}^{(9)}$. Pemanfaatan informasi buku KIA dapat didefinisikan sebagai tindakan ibu dalam menggunakan buku KIA untuk mencari informasi gizi balita dan sebagai sumber pencatatan dalam memonitoring gizi balita.

Pemantauan tumbuh kembang anak perlu dilakukan secara rutin antara lain dengan menggunakan Kartu Menuju Sehat (Buku KIA), dengan kartu ini setiap ada penyimpangan tumbuh kembang anak dapat segera diketahui sedini mungkin. Pemanfaatan Buku KIA sebagai alat untuk memantau kesehatan dan gizi balita perlu dimasyarakatkan sehingga pemantauan balita akan diperoleh manfaat yang besar apabila dilakukan pada semua balita yang ada pada suatu daerah, namun untuk dapat melaksanakan hal ini bukanlah merupakan suatu yang mudah karena banyak faktor yang mempengaruhi pemanfaatan Buku KIA balita itu sendiri ${ }^{(7)}$.

Pengisian buku KIA seyogyanya memberikan pemahaman pada ibu tentang status kesehatan diri dan anaknya. Catatan yang lengkap akan mendukung peningkatan pengetahuan ibu tentang kesehatan diri dan kesehatan anak-anak seperti kelengkapan tumbuh kembang anak. Deteksi dini kelainan pertumbuhan dan perkembangan anak akan sangat berguna, agar diagnosis maupun upaya pemulihan dapat dilakukan lebih awal, sehingga pertumbuhan dan perkembangan anak dapat berlangsung seoptimal mungkin ${ }^{(9)}$.

Studi pendahuluan yang dilakukan di Desa Margakaya pada 10 buku KIA milik balita didapatkan masih terdapat beberap kolom yang kosong pada buku KIA terutama pada bagian gizi balita. Beberapa identifikasi disebabkan masih kurangnya ibu dalam memanfaatkan informasi yang terdapat dalam buku KIA. Penelitian ini betujuan untuk melihat hubungan pemanfaatan informasi tentang balita usia 0-59 bulan pada buku KIA dengan kelengkapan pencatatan status gizi di Buku KIA di Desa Margakaya Pringsewu Lampung.

\section{Metode}

Penelitian ini mengunakan desain studi observasional analitik dengan pendekatan crossetional untuk menganalisis variabel sebab dan akibat yang terjadi pada objek penelitian yang dikumpulkan dalam waktu bersamaan. Populasi adalah ibu yang mempunyai anak berusia kurang dari usia 12-59 bulan yang berada di desa Margakaya tahun 2017, berjumlah 240 orang. Besar sampel dihitung menggunakan total sampling yang didapatkan sebanyak 226 orang jumlah sampel yang memenuhi kriteria. Kriteria inklusi adalah ibu yang berdomisili di Desa Margakaya Pringsewu Lampung dan mempunyai buku KIA. Observasi fungsi pencatatan buku KIA dilakukan pada buku pemahaman ibu tentang informasi yang tertera di buku KIA anak. 
Kriteria eksklusi adalah ibu yang memiliki sakit fisik, balita yang tidak diasuh langsung oleh ibunya dan Balita yang mengalami cacat fisik. Penilaian Pemanfaatan Informasi Tentang Balita Usia 0-59 Bulan Pada Buku KIA. Data pemanfaatan informasi KIA ibu diperoleh melalui wawancara menggunakan kuesioner terstruktur Kriteria dikatakan pemanfaatan baik bila hasil kuesioner lebih dari nilai median baku (>65\%) dan dikatakan kurang bila pemanfaatan kurang dari median baku $(\leq 65 \%)$. Penilaian kelengkapan pencatatan tumbuh kembang di buku KIA berdasarkan observasi buku KIA yang dimiliki oleh ibu. Observasi kelengkapan buku KIA meliputi identitas ibu dan anak, catatan kesehatan ibu hamil, bersalin dan nifas, kunjungan neonatal, catatan imunisasi dan pemberian vitamin, catatan Kartu Menuju Sehat (KMS) dan catatan perkembangan pada anak. Kriteria pencatatan lengkap bila dalam buku KIA ditulis lengkap dalam setiap kolom, sedangkan pada catatan yang kurang lengkap bila hasil catatan buku KIA tidak lengkap. Data dianalisis menggunakan analisis univariat meliputi karakteristik balita, pemanfaatan informasi buku KIA dan kelengkapan catatan buku KIA. Analisis bivariat menggunakan uji statistik dengan uji chi square dengan nilai $C I$ $95 \%$.

\section{Hasil}

Analisis Univariat

Tabel 1 Distribusi Frekuensi Pemanfaatan Informasi Tentang Balita Usia 0-59 Bulan Pada Buku KIA di Desa Margakaya Pringsewu Lampung

\begin{tabular}{lcc}
\hline \multicolumn{1}{c}{$\begin{array}{c}\text { Pemanfaatan } \\
\text { informasi }\end{array}$} & $\begin{array}{c}\text { Frekuensi } \\
(\mathrm{n})\end{array}$ & $\begin{array}{c}\text { Persentase } \\
(\%)\end{array}$ \\
\hline Kurang & 88 & 38.9 \\
Baik & 138 & 61.1 \\
\hline Total & 226 & 100.0 \\
\hline
\end{tabular}

Pada tabel 1 menjelaskan bahwa sebagian besar orang tua memanfaatkan informasi tentang tumbuh kembang balita yang ada di buku KIA dengan baik (61.1\%), sedangkan sisanya kurang dapat memanfaatkan informasi informasi tentang tumbuh kembang balita yang ada di buku KIA (38.9\%).

Tabel 2 Distribusi Frekuensi Kelengkapan Pencatatan Tumbuh Kembang di Buku KIA di Desa Margakaya Pringsewu Lampung

\begin{tabular}{lcc}
\hline $\begin{array}{c}\text { Kelengkapan } \\
\text { Pencatatan } \\
\text { tumbuh kembang }\end{array}$ & $\begin{array}{c}\text { Frekuensi } \\
(\mathrm{n})\end{array}$ & $\begin{array}{c}\text { Persentase } \\
(\%)\end{array}$ \\
\hline Tidak Lengkap & 33 & 14.6 \\
Lengkap & 193 & 85.4 \\
\hline Total & 226 & 100.0 \\
\hline
\end{tabular}

Pada tabel 2 menjelaskan bahwa sebagian besar orang tua Pencatatan Tumbuh Kembang di Buku KIA dengan lengkap (85.4\%), sedangkan sisanya kurang lengkap pada Pencatatan Tumbuh Kembang di Buku KIA $(14,6 \%)$ 
Dzul Istiqomah Hasyim, Apri Sulistianingsih. Pemanfaatan Informasi Tentang Balita Usia 12-59 Bulan Pada Buku KIA Dengan Kelengkapan Pencatatan Status Gizi Di Buku KIA

Doi :

\section{Analisis Bivariat}

Tabel 3 Hubungan Pemanfaatan Informasi Tentang Balita Usia 12-59 Bulan Pada Buku KIA Dengan Kelengkapan Pencatatan Tumbuh Kembang di Buku KIA di Desa Margakaya Pringsewu Lampung

\begin{tabular}{|c|c|c|c|c|c|c|c|c|}
\hline \multirow{3}{*}{$\begin{array}{c}\text { Pemanfaatan } \\
\text { informasi buku } \\
\text { KIA }\end{array}$} & \multicolumn{4}{|c|}{$\begin{array}{l}\text { Kelengkapan Pencatatan } \\
\text { tumbuh kembang }\end{array}$} & \multicolumn{4}{|c|}{ Total } \\
\hline & & Tidak & \multicolumn{2}{|c|}{ Lengkap } & \multirow{2}{*}{$\mathrm{N}$} & \multirow{2}{*}{$\%$} & \multirow{2}{*}{ P-Value } & \multirow{2}{*}{$\begin{array}{c}\text { OR } \\
95 \% \mathrm{CI}\end{array}$} \\
\hline & $\mathrm{n}$ & $\%$ & $\mathrm{n}$ & $\%$ & & & & \\
\hline Kurang & 29 & 33.0 & 59 & 67.0 & 88 & 38.9 & \multirow{3}{*}{$<0.001 *$} & \multirow{3}{*}{$\begin{array}{c}16.466 \\
(5.540-38.941)\end{array}$} \\
\hline Baik & 4 & 2.9 & 134 & 97.1 & 138 & 61.1 & & \\
\hline TOTAL & 33 & & 193 & & 226 & & & \\
\hline
\end{tabular}

Berdasarkan tabel 3 diketahui bahwa responden menggunakan buku KIA sebagai media informasi tentang tumbuh kembang balita 12-59 bulan dengan baik dan memiliki catatan lengkap sebanyak $97.1 \%$ dan sisanya memanfaatkan informasi dengan baik namun memiliki pencatatan tumbuh kembang yang tidak lengkap sebanyak $2.9 \%$, sedangkan menggunakan pemanfaatan informasi buku KIA tentang tumbuh kembang balita 0-59 bulan dengan kurang dan memiliki catatan lengkap sebanyak $67.0 \%$ dan sisanya memanfaatkan informasi dengan kurang dan memiliki pencatatan tumbuh kembang yang tidak lengkap sebanyak 33.0\%. Dari tabel diatas dapat disimpulkan bahwa semakin ibu menggunakan pemanfaatan informasi buku KIA tentang tumbuh kembang balita 12-59 bulan dengan baik dan semakin lengkap catatan tumbuh kembang balita di buku KIA.

Hasil uji statistik diperoleh nilai $\rho \leq 0.001$, maka HA di terima dan H0 ditolak. Hal ini berarti dari hasil penelitian menunjukan adanya Hubungan Pemanfaatan Informasi Tentang Balita Usia 12-59 Bulan Pada buku KIA dengan kelengkapan pencatatan status gizi di buku KIA di Desa Margakaya Pringsewu
Lampung. Secara statistik diperoleh nilai $\mathrm{OR}=$ 16.466 (5.540 - 38.941). Berdasarkan nilai OR dapat dihasilkan bahwa ibu yang tidak memanfaatkan informasi pada buku KIA memiliki risiko 16 kali catatan gizi balita tidak lengkap dibandingkan ibu yang memanfaatkan informasi tentang balita 12-59 bulan di buku KIA.

\section{Pembahasan}

Buku KIA adalah buku catatan terpadu yang digunakan dalam keluarga dengan tujuan meningkatkan praktik keluarga dan masyarakat dalam pemeliharaan atau perawatan kesehatan ibu dan anak serta meningkatkan kualitas pelayanan KIA. Pencatatan buku KIA dilakukan oleh bidan desa serta dan dapat dibantu oleh kader dalam penyelenggaraan posyandu.

Pada hasil penelitian ini pencatatan buku KIA yang lengkap lebih banyak dilakukan oleh ibu yang memanfaatkan buku KIA dengan baik dibandingkan ibu yang kurang memanfaatkan buku KIA. Pengisian buku KIA seyogyanya memberikan pemahaman pada ibu tentang status kesehatan diri dan anaknya. Penggunaan buku KIA oleh ibu merupakan salah satu 
intervensi dalam upaya peningkatan informasi. Catatan yang lengkap akan mendukung peningkatan pengetahuan ibu tentang kesehatan diri dan kesehatan anak-anak ${ }^{(8)}$.

Penelitian di Jepang menunjukkan bahwa buku Kesehatan Ibu dan Anak merupakan alat yang digunakan hampir semua orang tua di Jepang sebagai alat pencatatan yang dibagikan orang tua selama periode kehamilan sampai balita. Salah satu informasi pada buku ini pertumbuhan anak dan gizi pada anak. Informasi pada buku KIA dapat meningkatkan pengetahuan sehingga digunakan orang tua sebagai deteksi dini gangguan pertumbuhan dan perkembangan pada anak ${ }^{(10)}$.

Hasil pada penelitian ini didapatkan bahwa adanya Hubungan Pemanfaatan Informasi Tentang Balita Dengan Kelengkapan Pencatatan Status Gizi di Buku KIA di Desa Margakaya Pringsewu Lampung. Pemanfaatan buku KIA oleh tenaga kesehatan perlu dimodifikasi,khususnyadalam menggabungkan informasi/ pesan supaya lebih menarik, mudah dipahami sebagai cara untuk menyampaikan pesan tersebut. Tenaga kesehatan juga perlu mempertimbangkan tingkat pendidikan kelompok sasaran. Hal tersebut merupakan upaya peningkatan efektivitas kegiatan berbasis masyarakat dalam mempromosikan pengetahuan dan perilaku ibu dalam kesehatan ibu dan anak. Pemanfaatan buku KIA dalam sesi pendidikan kesehatan akan mendorong komunikasi yang efektif antara ibu dengan tenaga kesehatan. Dukungan tenaga kesehatan dapat diberikan ketika ibu memanfaatkan fasilitas pelayanan kesehatan, tenaga kesehatan dapat menjelaskan poin penting karena ibu belum memahami informasi kesehatan ibu dan anak $^{(8)}$. Bentuk dukungan kesehatan dapat berupa pemberian edukasi sejak masa kehamilan. Hal ini bertujuan untuk meningkatkan pengetahuan ibu tentang pentingnya pencatatan gizi balita, selain itu kelengkapan pencatatan buku KIA pada balita dapat menjadi deteksi dini pada gangguan status gizi balita.

Pemanfaatan buku KIA dapat menjadi media bagi ibu untuk memahami kondisi kesehatan ibu dan anak. Keluarga juga akan bisa memahami penggunaan Buku KIA sehingga ada tiga fungsi buku KIA (fungsi pencatatan, fungsi pendidikan dan fungsi komunikasi) bisa dimaksimalkan ${ }^{(8)}$. Ibu yang memiliki buku KIA lebih sering berkunjung ke pelayanan kesehatan dibandingkan dengan ibu yang tidak memiliki buku KIA. Meskipun ibu yang memiliki buku KIA pengetahuannya kurang, tetapi ibu akan terbiasa dengan informasi kesehatan yang telah diberikan oleh tenaga kesehatan yang menggunakan buku KIA sebagai pedoman untuk memberikan informasi. Sehingga, penggunaan buku KIA ini dinilai sangat penting terutama untuk memelihara kesehatan ibu dan anak balita ${ }^{(11)}$.

Menurut Sarasati (2016), buku KIA merupakan alat untuk mendeteksi secara dini adanya gangguan atau masalah kesehatan ibu dan anak, alat komunikasi dan penyuluhan dengan informasi yang penting bagi ibu, keluarga dan masyarakat mengenai pelayanan kesehatan ibu dan anak termasuk rujukannya dan standar pelayanan KIA, gizi, imunisasi dan tumbuh kembang balita. Dalam pengisian buku 
Dzul Istiqomah Hasyim, Apri Sulistianingsih. Pemanfaatan Informasi Tentang Balita Usia 12-59 Bulan Pada Buku KIA Dengan Kelengkapan Pencatatan Status Gizi Di Buku KIA Doi :

KIA belum dilakukan dengan optimal karena masih ada buku KIA yang pengisiannya belum lengkap. Bagian yang tidak diisi yaitu pada nasehat pemenuhan gizi dan pemberian makan, Stimulasi Deteksi Intervensi Dini Tumbuh Kembang, serta catatan kesehatan anak, dari 10 buku KIA sebesar $100 \%$ pada catatan tersebut tidak terisi ${ }^{(12)}$.

Berdasarkan tabel 3 diketahui bahwa responden menggunakan pemanfaatan informasi buku KIA tentang tumbuh kembang balita 12-59 bulan dengan kurang dan memiliki catatan lengkap sebanyak $67.0 \%$ dan sisanya memanfaatkan informasi dengan kurang dan memiliki pencatatan tumbuh kembang yang tidak lengkap sebanyak $33.0 \%$. Hal ini disebabkan oleh faktor lain yang mendasari ibu untuk dapat merekam status gizi balita di buku KIA.

Sejalan dengan penelitian yang dilakukan oleh Therra Tahun 2012 yang menjelaskan bahwa tidak ada hubungan pemanfaatan buku KIA dengan perawatan balita. Hal ini dapat disebabkan oleh banyak faktor informasi lain yang dapat meningkatkan minat dan perilaku ibu untuk mengecek status gizi balitanya $^{(13)}$.

Di era teknologi yang maju ini ibu tidak lagi mendapatkan informasi tentang gizi anak hanya melalui buku KIA. Banyaknya sumber lain yang dapat ibu peroleh misalnya melalui televisi, majalah, ataupun dari brosur yang beredar Apalagi di zaman sekarang semakin banyak ibu yang sudah mengetahui dan mencari tahu hal-hal terkait mengenai gizi anaknya melalui internet. Hal ini menunjukkan bahwa buku KIA bukan satu-satunya informasi mengenai gizi anak balita yang dapat diperoleh ibu. Selain itu juga, pada penelitian ini instrument berupa kuesioner dibangun sendiri oleh peneliti menggunakan informasi yang didapatkan dari buku KIA. Hal ini mungkin merupakan factor lain yang menyebabkan tidak adanya hubungan antara variabel bebas dan terikat, meskipun kuesioner yang diberikan kepada ibu telah divalidasi terlebih dahulu sebelumnya ${ }^{(11)}$.

Hasil penelitian ini yang menunjukkan bahwa bahwa ibu yang memanfaatkan buku KIA tentang tumbuh kembang balita 12-59 bulan dengan baik, maka catatan tumbuh kembang balita di buku KIA lebih lengkap. Diharapkan ibu menggunakan buku KIA dan meningkatkan pengetahuan ibu tentang pentingnya monitoring status gizi balita maka perlu dilakukan pendidikan yang bekelanjutan bagi ibu.

Peran bidan sangatlah besar dalam meningkatkan kelengkapan catatan KIA pada balita. Berdasarkan dari penelitian yang Sarasati (2016) yang menelaskan bahwa beberapa faktor yang berhubungan dengan kelengkapan pengisian buku KIA diantaranya adalah pengetahuan, sikap dan keterampilan bidan. Pengetahuan, sikap dan keterampilan bidan berpengaruh terhadap kemampuan dalam memahami buku KIA dan memberikan edukasi kepada ibu untuk memanfaatkan buku KIA. Oleh karena itu, untuk memperbaiki kelengkapan pengisian, maka perlu ditingkatkan pengetahuan dan keterampilan bidan desa secara bersama-sama. Hal ini dapat dilakukan dengan memberikan pelatihan 
dengan metode belajar berdasarkan masalah atau kondisi ibu dan anak ${ }^{(12)}$.

Sejalan dengan penelitian Mariani (2013) yang dilakukan di Kabupaten Nagan Rata, dijelaskan bahwa pengetahuan berhubungan signifikan dengan pemanfaatan buku KIA oleh orang tua balita. Ibu yang memiliki pengetahuan baik akan lebih memanfaatkan buku KIA dalam pemantauan gizi balitanya. Namun demikian, pemanfaatn buku KIA dalam penelitian ini tidak berhubungan dengan peran tenaga kesehatan. Hal ini dapat menjadi masukan bahwa selain tenaga kesehatan juga terdapat beberapa hal yang dapat meningkatkan pemantaatan buku $\mathrm{KIA}^{(7)}$.

Salah satu faktor lainnya adalah peran kader di di desa dalam memberikan motivasi ibu untuk aktif di posyandu, Sehingga ibu mendapatkan edukasi dan memanfaatkan informasi yang terdapat dalam buku KIA. Hal ini sesuai dengan penelitian Wijhati tahun 2017 bahwa peran kader berhubungan dengan pemanfaatan buku KIA oleh ibu, kader yang berperan baik kemungkinan ibu dalam memanfaatkan buku KIA sebesar 1.655 kali dibanding kader yang perannya kurang ${ }^{(14)}$. Jika Kader Posyandu melaksanakan tugasnya dengan baik maka akan berdampak positif terhadap pengelolaan buku KIA ${ }^{(15)}$.

\section{Kesimpulan}

Kesimpulan pada penelitian ini didapatkan bahwa pemantaan informasi buku KIA pada ibu dapat meningkatkan kelengkapan pencatatan status gizi pada buku KIA di Desa Margakaya Pringsewu Lampung.

\section{Saran}

Pentingnya informasi yang terdapat di dalam buku KIA menjadi tugas bagi tenaga kesehatan dan kader untuk meningkatkan pengetahuan ibu tentang pentingnya buku KIA dalam pemantauan gizi balita sebagai upaya pencegahan gangguan gizi pada balita. Disarankan bagi tenaga kesehatan untuk dapat bekerja sama dengan kader setempat dalam memberikan edukasi yang baik kepada ibu balita tentang manfaat yang ada di buku KIA. Buku KIA dapat memberikan informasi yang berguna bagi balita terutama status gizi pada balita.

\section{Daftar Pustaka}

1. Soetjiningsih. Tumbuh Kembang Anak. Jakarta: Egc; 2015.

2. Statistic Indonesia. Indonesia Demograpic And Health Survey 2012. Jakarta: Departemen Kesehatan, 2013.

3. Sandra Ar. Hubungan Antara Pemanfaatan Buku Kia Dan Kepatuhan Imunisasi Di Puskesmas Ciputat Timur Kota Tangerang Selatan Depok: Universitas Indonesia; 2011.

4. Nakamura Y. Maternal And Child Health Handbook In Japan. Jmaj. 2017;53(4):7.

5. Mudany Ma, Sireng M, Rutherford Gw, Mwangi M, Nganga Lw, Gichangi A. Enhancing Maternal And Child Health Using A Combined Mother \& Child Health Booklet In Kenya. J Trop Pediatr. 2017;61(6):7.

6. Kesehatan D. Profil Kesehatan Provinsi Lampung Tahun 2014. Bandar Lampung: Dinas Kesehatan Provinsi Lampung, 2015.

7. Mariani. Faktor-Faktor Yang Berpengaruh Terhadap Pemanfaatan Buku Kesehatan Ibu Dan Anak Oleh Ibu Balita Di Desa Latong Kecamatan Seunagan Kabupaten Nagan Raya Tahun 2013. Aceh Barat: Universitas Teuku Umar; 2013.

8. Sistiarani C, Gamelia E, Purnama Sari Du. Fungsi Pemanfaatan Buku Kia Terhadap Pengetahuan Kesehatan Ibu Dan Anak 
Dzul Istiqomah Hasyim, Apri Sulistianingsih. Pemanfaatan Informasi Tentang Balita Usia 12-59 Bulan Pada Buku KIA Dengan Kelengkapan Pencatatan Status Gizi Di Buku KIA

Doi :

Pada Ibu. Jurnal Kesehatan Masyarakat Nasional. 2014;8(8):6.

9. Dardjito E, Sistiarani C, Nurhayati S. Deteksi Pertumbuhan Dan Perkembangan Balita Melalui Penggunaan Buku Kia. Jurnal Kesmasindo. 2014;6(3):11.

10. Takeuchi J, Sakagami Y, Perez Rc. The Mother And Child Health Handbook In Japan As A Health Promotion Tool: An Overview Of Its History, Contents, Use, Benefits, And Global Influence. Global Pediatric Health. 2016;3(9):9.

11. Adiningrum F, Sukandar H, Wijaya M. Hubungan Antara Pengetahuan Ibu Tentang Buku Kia Dengan Status Gizi Anak Balita Di Kecamatan Soreang Kabupaten Bandung. Jsk. 2016;2(2):7.

12. Sarasati Ra, Mawarni A, Dharmawan Y. Hubungan Beberapa Faktor Dengan Kelengkapan Pengisian Buku Kesehatan Ibu Dan Anak Oleh Bidan Desa Di Wilayah Kerja Puskesmas Jepara Tahun 2016. Jurnal Kesehatan Masyarakat. 2016;4(4):8.

13. Therra Mt. Hubungan Pengetahuan Pemanfaatan Buku Kia Dengan Kemampuan Perawatan Balita Di Posyandu Laras Lestari Nogotirto Yogyakarta. Yogyakarta: Stikes Aisyiyah Yogyakarta; 2012.

14. Wijhati Er, Suryantoro P, Rokhanawati D. Optimalisasi Peran Kader Dalam Pemanfaatan Buku Kia Di Puskesmas Tegalrejo Kota Yogyakarta. Jurnal Kebidanan,. 2017;6(2):8.

15. Widagdo L, Husodo Bt. Pemanfaatan Buku Kia Oleh Kader Posyandu: Studi Pada Kader Posyandu Di Wilayah Kerja Puskesmas Kedungadem Kabupaten Bojonegoro. Makara, Kesehatan. 2009;13(1):9. 